\title{
ANALIZA TRENDÓW ZDARZEŃ LOTNICZYCH Z WYKORZYSTANIEM INTEGRACJI BAZ DANYCH
}

\author{
Mikołaj Wysocki, Maciej Lasek \\ Politechnika Warszawska, Wydziat Mechaniczny Energetyki i Lotnictwa \\ e-mail:maciej.lasek@pw.edu.pl
}

\begin{abstract}
W artykule - przy zastosowaniu metody integracji baz danych - poddano analizie zdarzenia lotnicze zgłoszone do PKBWL w latach 2003-2015. Zastosowanie metody integracji baz danych do analiz tego typu faktów odznacza się nowością oraz efektywnością, pozwoliło bowiem na porównywanie danych w szerokim zakresie. Im bardziej szczegółowe dane poddawano analizie, tym więcej można było wskazać przyczyn zdarzeń i ich powiązań z okolicznościami ich wystąpienia. Na podstawie autorskiego współczynnika ustalono, że można określić zgłaszalność zdarzeń, a także, że wzrost liczby wykonywanych lotów powodował coraz większą liczbę zdarzeń, co wydaje się zjawiskiem logicznym, ale zarazem nie powodował on wzrostu liczby ofiar śmiertelnych. Bardziej szczegółowej analizie poddano zdarzenia z udziałem szybowców. W tym obszarze udało się powiązać przyczyny zdarzenia z charakterem oraz fazą lotu. Potwierdzono, iż największa ich liczba występuje w fazie lądowania i ma związek z błędem człowieka.
\end{abstract}

\section{Wprowadzenie}

Każdy środek transportu stworzony przez człowieka wiąże się z ryzykiem wypadku. Lotnictwo od początki swojego istnienia nie było wyjątkiem. Natomiast to co je wyróżniało, to wysokie ryzyko śmierci lub obrażeń w przypadku awarii lub katastrofy. Dlatego od samego początku osoby oraz instytucje związane z lotnictwem za cel postawiły sobie niezawodność tego sposobu komunikacji. Jednym z przykładów dążenia do doskonałości jest bardzo wnikliwe badanie każdego incydentu, aby w pełni poznać jego przyczyny i w przyszłości starać się zapobiec podobnym sytuacjom.

Aby zrozumieć większą liczbę danych, konieczne jest odpowiednie podejście statystyczne. $\mathrm{W}$ poniższej pracy skupiono się na zbadaniu przydatności takiego podejścia w zidentyfikowaniu obszarów najbardziej niebezpiecznych a także w wyznaczeniu trendów zmian na przestrzeni lat 2003-2015.

Jako podstawę analizy wykorzystano dane zdarzeń zgłoszonych do Państwowej Komisji Badań Wypadków Lotniczych (PKBWL). Dodatkowe informacje dotyczące liczby wydanych licencji oraz liczby operacji lotniczych zostały pozyskane ze strony Urzędu Lotnictwa Cywilnego (ULC).

Przed wykonaniem analiz konieczne było przygotowanie danych. Kluczowe dla tej analizy parametry zostały wystandaryzowane, a łączenie danych odbyło się z wykorzystanie zaawansowanych funkcji programu Microsoft Excel, co umożliwiło intuicyjną wizualizację wyników analiz.

Na początku skupiono się na ogólnej analizie zgłaszalności zdarzeń lotniczych. Porównano zmiany liczby zgłoszeń w różnych segmentach lotnictwa ze wzrostami liczby użytkowników przestrzeni powietrznej. Następnie skoncentrowano się na zdarzeniach lotnictwa General Aviation. Głównym celem było przeanalizowanie zdarzeń, których uczestnicy odnieśli rany lub ponieśli śmierć. W końcu dokonano szczegółowej interpretacji danych zawartych w raportach dotyczących zdarzeń z udziałem szybowców.

W pracy (na rysunkach i w tabelach) używane są powszechnie przyjęte skróty z języka angielskiego: CA - Commercial Aviation, GA - General Aviation, M - Military. 


\section{Statystyki ogólne}

Przed szczegółową analizą poszczególnych czynników wpływających na zdarzenia lotnicze należy zwrócić uwagę na prawie nieprzerwany wzrost liczby zgłoszeń zdarzeń od początku rozpatrywanego okresu. W porównaniu z rokiem 2003 liczba napływających zgłoszeń wzrosła 10krotnie. W zdecydowanej większości wzrost dotyczy zgłoszeń z segmentu lotnictwa komercyjnego - w ciągu 12 lat wzrost o ponad $4400 \%$. Wzrost liczby zgłoszeń był również zauważalny w wypadku General Aviation, jednak był on zdecydowanie mniejszy - 206\% w tym samym okresie (rys. 1). Dokładne wartości przedstawione zostały w tabeli 1.

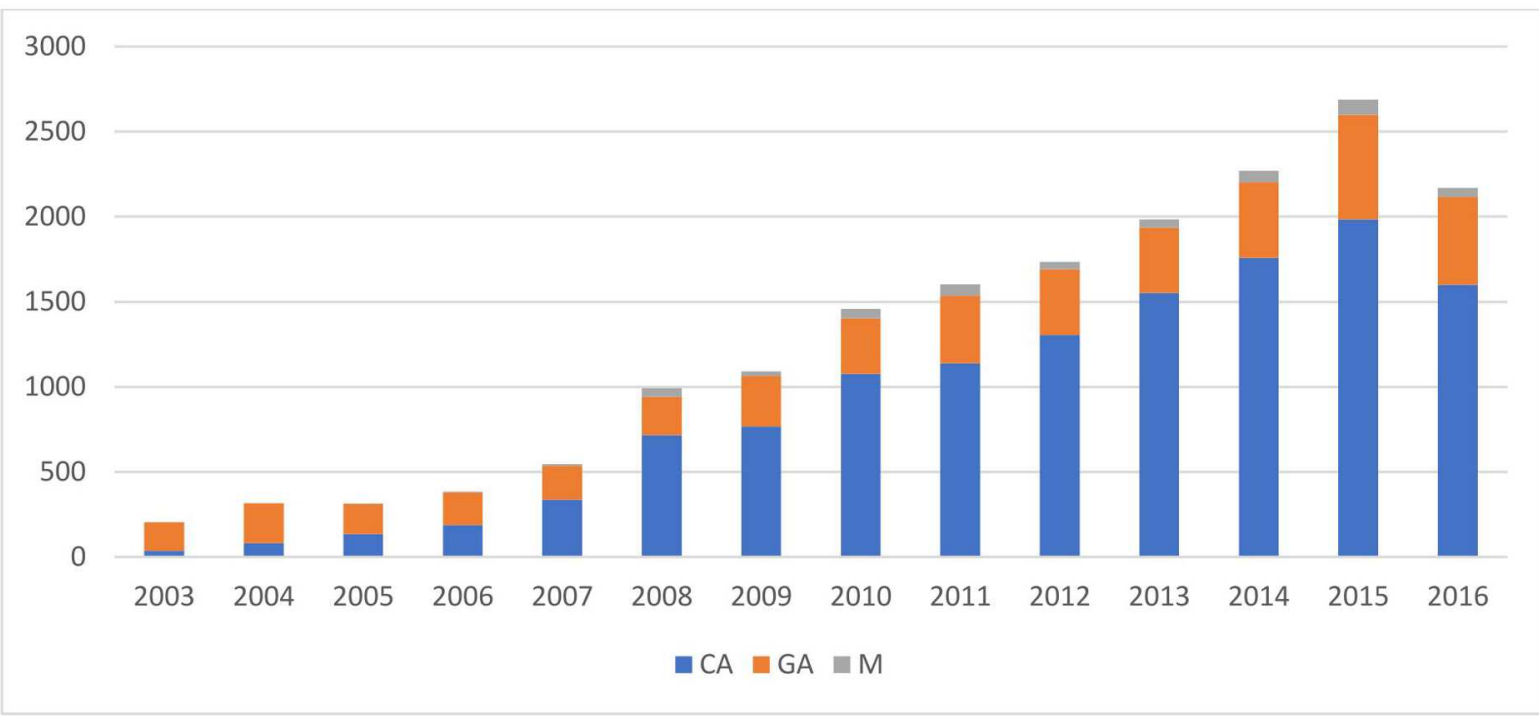

Rys. 1. Liczba zdarzeń w latach (rok 2016 - dane do września)

Tabela 1. Liczba zdarzeń w latach

\begin{tabular}{|c|c|c|c|c|}
\hline Rok & CA & GA & M & Razem \\
\hline \hline 2003 & 35 & 169 & - & 204 \\
\hline 2004 & 83 & 231 & 1 & 315 \\
\hline 2005 & 135 & 178 & 2 & 315 \\
\hline 2006 & 187 & 193 & 4 & 384 \\
\hline 2007 & 336 & 199 & 11 & 546 \\
\hline 2008 & 715 & 226 & 51 & 992 \\
\hline 2009 & 766 & 299 & 26 & 1091 \\
\hline 2010 & 1076 & 326 & 56 & 1458 \\
\hline 2011 & 1138 & 397 & 68 & 1603 \\
\hline 2012 & 1305 & 385 & 44 & 1734 \\
\hline 2013 & 1552 & 384 & 49 & 1985 \\
\hline 2014 & 1759 & 444 & 66 & 2269 \\
\hline 2015 & 1984 & 614 & 89 & 2687 \\
\hline 2016 & 1599 & 517 & 54 & 2170 \\
\hline
\end{tabular}

Prezentując dane podług kryterium miesiąca ich zgłoszenia zgodnie z miesiącem zgłoszenia, możemy zauważyć, że znacznie więcej incydentów przypada na miesiące letnie (rys. 2).

Ta tendencja jest szczególnie widoczna w wypadku operacji General Aviation (rys. 3a). Aż $43 \%$ zdarzeń zgłoszonych w latach 2003-2016 miało miejsce w III kwartale, co przypada na wakacyjny szczyt sezonu. Niewiele mniej - 37\% zgłoszeń dotyczyło kwartału II. Na kwartał I 


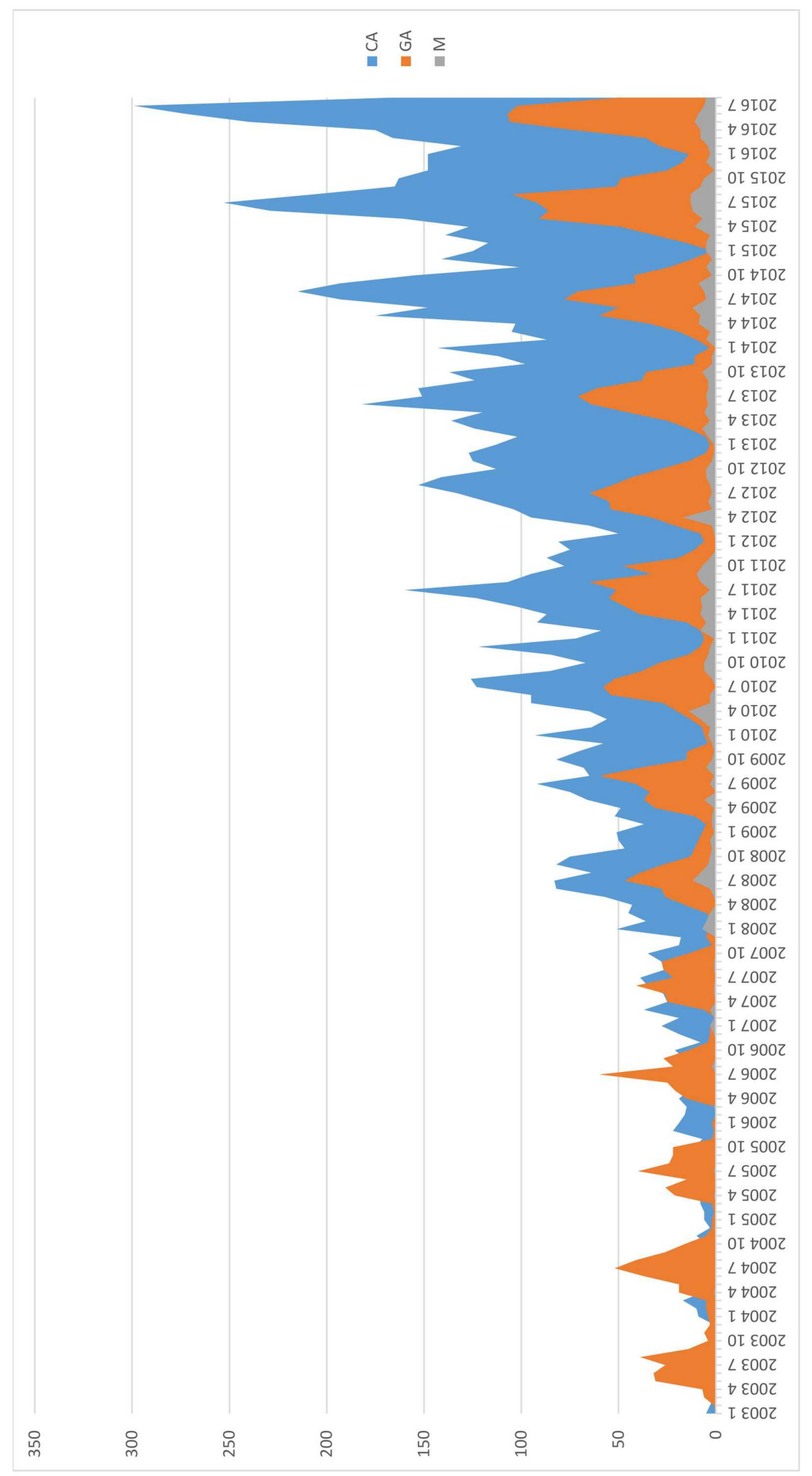

Rys. 2. Liczba zdarzeń miesięcznie (rok 2016 - dane do września) 
oraz IV przypada w sumie jedynie $20 \%$ zgłoszeń z tego segmentu, odpowiednio $7 \%$ oraz $13 \%$. W okresie jesienno-zimowym warunki pogodowe często uniemożliwiają loty mniejszych samolotów. Dodatkowo niskie temperatury powodują, że warunki o tej porze roku nie są komfortowe dla pilotów rekreacyjnych (tabela 2).

Wpływ pory roku jest mniej zauważalny w wypadku lotnictwa komercyjnego. Również w III kwartale liczba zgłoszeń jest największa z tego segmentu - 31\%. Można to powiązać ze zwiększoną liczbą operacji czarterowych odbywających się w tym czasie obok połączeń regularnych.

Warto zwrócić również uwagę na dzień, w którym dochodzi do zgłaszanych zdarzeń (rys. 3b). Zdecydowana większość zdarzeń GA dotyczy dni wolnych od pracy - sobót oraz niedziel. Natomiast w wypadku lotnictwa komercyjnego w weekendy zauważyć można spadek zdarzeń, który można powiązać ze zmniejszoną intensywnością operacji regularnych w te dni (tabela 3 ).

(a)

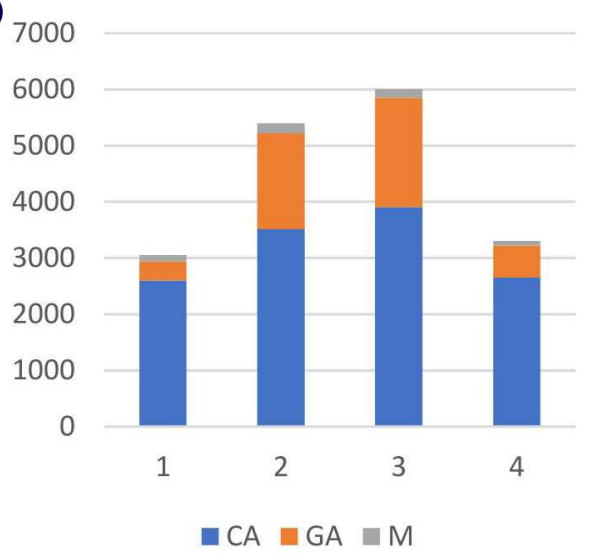

(b) 3000

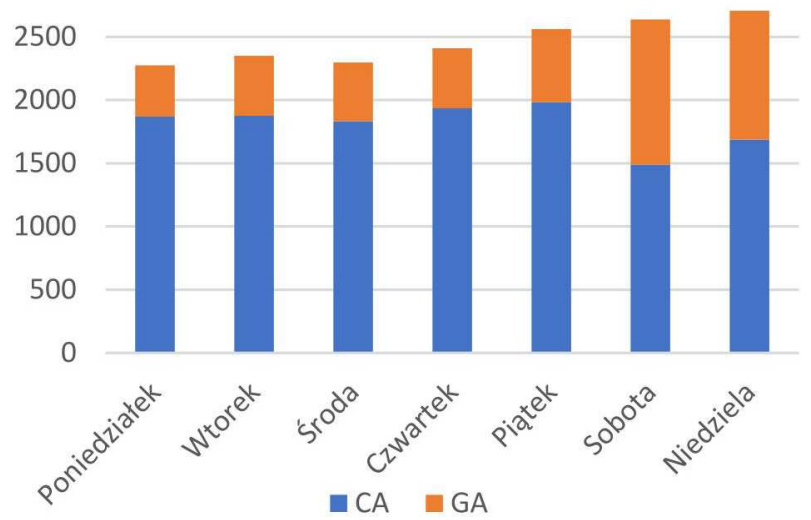

Rys. 3. Liczba zdarzeń: (a) w kwartałach, (b) w dniach tygodnia

Tabela 2. Liczba zdarzeń w kwartałach

\begin{tabular}{|c|c|c|c|c|c|}
\hline Kwartał & CA & GA & M & \%CA & \%GA \\
\hline \hline I & 2603 & 342 & 108 & $21 \%$ & $7 \%$ \\
\hline II & 3511 & 1706 & 181 & $28 \%$ & $37 \%$ \\
\hline III & 3908 & 1941 & 155 & $31 \%$ & $43 \%$ \\
\hline IV & 2649 & 575 & 78 & $21 \%$ & $13 \%$ \\
\hline
\end{tabular}

Tabela 3. Liczba zdarzeń w dniach tygodnia

\begin{tabular}{|l|c|c|c|}
\hline \multicolumn{1}{|c|}{ Dzień tyg. } & CA & GA & Suma \\
\hline \hline Poniedziałek & 1868 & 406 & 2274 \\
\hline Wtorek & 1874 & 475 & 2349 \\
\hline Środa & 1834 & 464 & 2298 \\
\hline Czwartek & 1935 & 473 & 2408 \\
\hline Piątek & 1984 & 577 & 2561 \\
\hline Sobota & 1489 & 1148 & 2637 \\
\hline Niedziela & 1687 & 1021 & 2708 \\
\hline
\end{tabular}

Wzrostu zgłoszeń każdego z poszczególnych segmentów nie możemy rozpatrywać w oderwaniu od rosnącej intensywności użycia przestrzeni powietrznej. Dla segmentu Genral Aviation liczbą, do której możemy się odnieść, aby móc analizować ten parametr, jest liczba licencji PPL 
wydanych przez ULC, natomiast dla lotnictwa komercyjnego liczba wykonanych operacji w roku kalendarzowym.

Korzystając z dostępnych danych o liczbie ważnych licencji (tabela 4), można zauważyć, że liczba licencji PPL w okresie od 2006 do 2019 wzrosła o $292 \%$, natomiast liczba licencji rekreacyjnych PPL oraz SPL tylko w okresie od 2013 do 2019 aż o 123\%. Z poniższych danych można wyciągnąć wniosek, że ruch rekreacyjny w polskiej przestrzeni powietrznej w 2019 roku był ponad dwukrotnie większy niż 6 lat wcześniej (rys. 4).

Tabela 4. Liczba licencji - stan na 31 XII 2019

\begin{tabular}{|c|c|c|c|c|c|}
\hline Rok & ATPL & CPL & PPL & SPL & Razem \\
\hline \hline 2006 & 1121 & 1204 & 1328 & 0 & 3653 \\
\hline 2007 & 1380 & 1399 & 1703 & 0 & 4482 \\
\hline 2008 & 1521 & 1683 & 2173 & 0 & 5377 \\
\hline 2009 & 1075 & 1320 & 2254 & 0 & 4649 \\
\hline 2010 & 951 & 1079 & 2063 & 0 & 4093 \\
\hline 2011 & 977 & 1187 & 2553 & 0 & 4717 \\
\hline 2012 & 995 & 1286 & 2951 & 0 & 5232 \\
\hline 2013 & 997 & 1326 & 3208 & 569 & 6100 \\
\hline 2014 & 1006 & 1375 & 3502 & 1553 & 7436 \\
\hline 2015 & 1017 & 1438 & 3689 & 2468 & 8612 \\
\hline 2016 & 1035 & 1508 & 3952 & 2657 & 9152 \\
\hline 2017 & 1123 & 1663 & 4246 & 2845 & 9877 \\
\hline 2018 & 1194 & 1805 & 4853 & 3051 & 10903 \\
\hline 2019 & 1279 & 1958 & 5207 & 3220 & 11664 \\
\hline
\end{tabular}

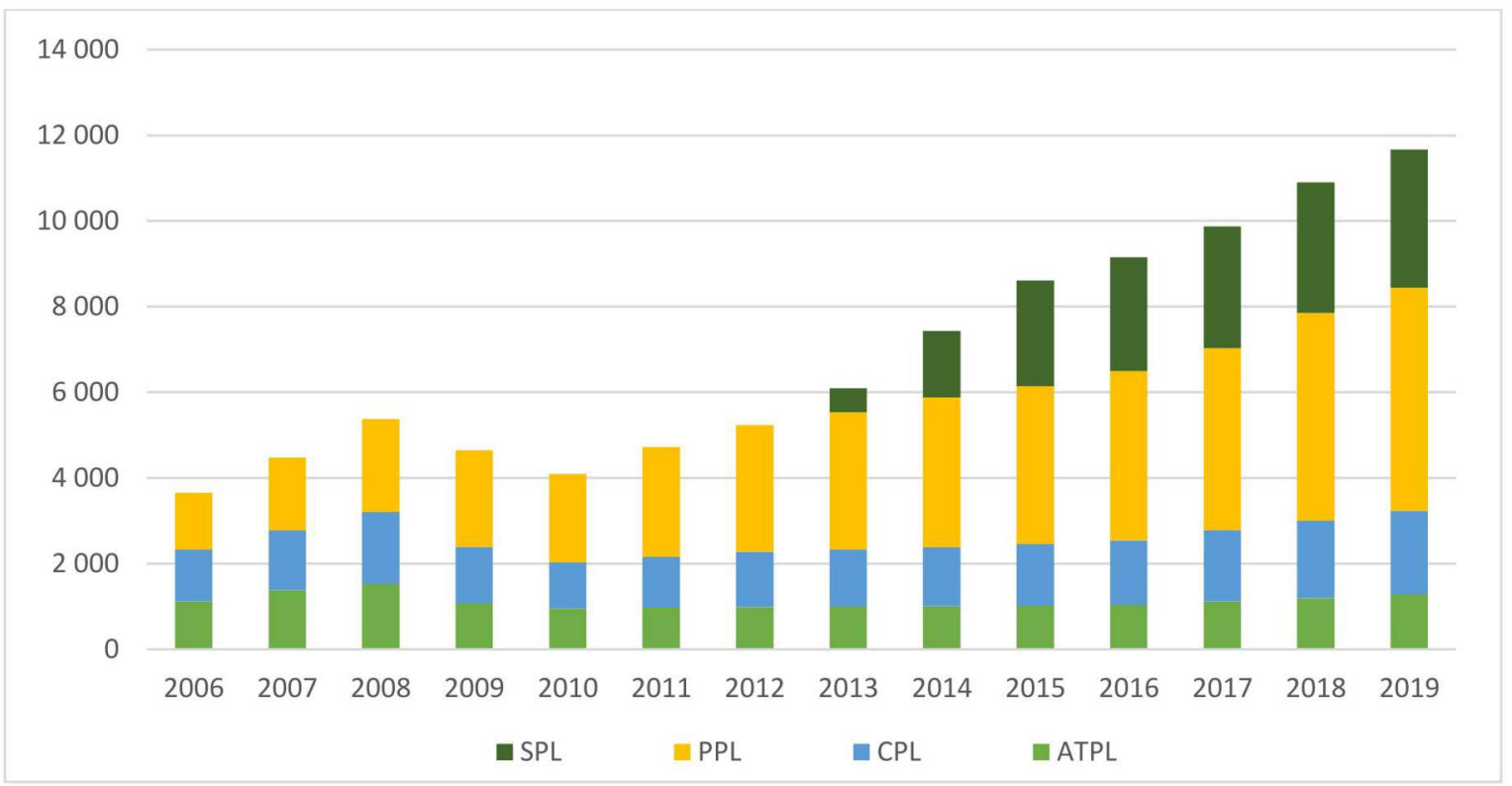

Rys. 4. Liczba ważnych licencji - stan na 31 XII 2019

W wypadku lotnictwa komercyjnego również zauważalny jest stały wzrost wykorzystania przestrzeni powietrznej (tabela 5). Liczba operacji lotniczych od 2003 do 2015 wzrosła o 37\%, a od 2015 do 2019 ten wzrost wyniósł aż 41\% (rys. 5). Wskazuje to na wysoką dynamikę rozwoju tego sektora w tym okresie 
Tabela 5. Liczba komercyjnych operacji lotniczych

\begin{tabular}{|c|c|}
\hline Rok & Liczba operacji \\
\hline \hline 2003 & 178036 \\
\hline 2004 & 179667 \\
\hline 2005 & 204111 \\
\hline 2006 & 236746 \\
\hline 2007 & 246759 \\
\hline 2008 & 257715 \\
\hline 2009 & 237858 \\
\hline 2010 & 240691 \\
\hline 2011 & 246679 \\
\hline 2012 & 276696 \\
\hline 2013 & 263073 \\
\hline 2014 & 268924 \\
\hline 2015 & 283924 \\
\hline 2016 & 309663 \\
\hline 2017 & 341199 \\
\hline 2018 & 381547 \\
\hline 2019 & 400213 \\
\hline
\end{tabular}

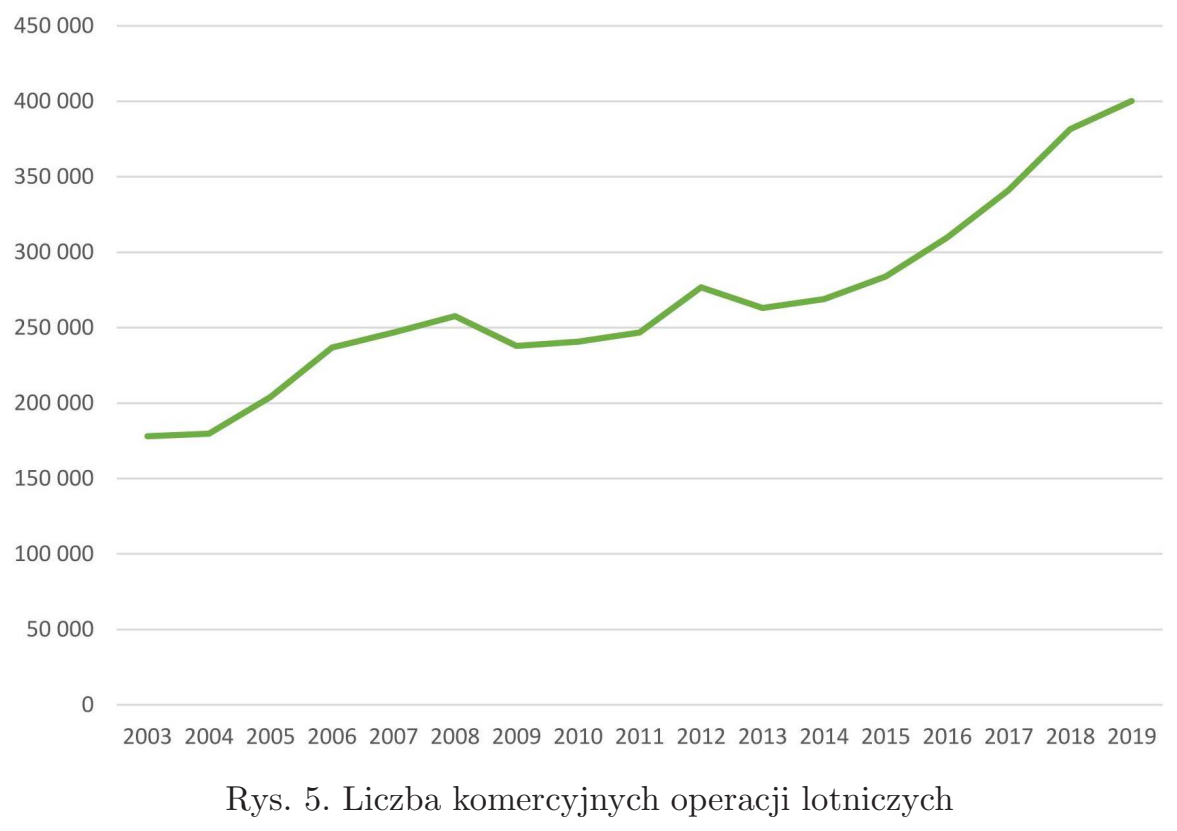

Aby ocenić, czy proporcjonalnie więcej zdarzeń jest zgłaszanych, należy wprowadzić wskaźnik zgłaszalności. Dla GA jest to liczba zgłoszeń podzielona przez liczbę licencji PPL z poprzedniego roku (ponieważ liczba oddaje stan na koniec roku). Aby analiza była wiarygodna, z liczby zdarzeń wyłączono tylko te, które dotyczyły samolotów (tabela 6).

Korzystając z powyższych danych, można zauważyć, że liczba licencji od roku 2006 do 2014 wzrosła o 178\%. W tym samym czasie od 2007 do 2015 roku liczba zgłoszonych zdarzeń wzrosła o 228\%. Oznacza to, że liczba zgłoszeń na licencje PPL wzrosła pod koniec tego okresu do 0,1396 w porównaniu do 0,1122 na jego początku (wzrost o 24\%) (tabela 7). Pozwala to wywnioskować, że wzrost liczby zgłoszeń powodowany jest głównie wzrostem liczby użytkowników przestrzeni powietrznej, a w mniejszym stopniu wzrostem zgłaszalności zdarzeń. 
Tabela 6. Liczba zgłoszeń zdarzeń GA - tylko samoloty

\begin{tabular}{|c|c|}
\hline Rok & Liczba zgłoszeń \\
\hline \hline 2003 & 153 \\
\hline 2004 & 183 \\
\hline 2005 & 136 \\
\hline 2006 & 141 \\
\hline 2007 & 149 \\
\hline 2008 & 148 \\
\hline 2009 & 217 \\
\hline 2010 & 255 \\
\hline 2011 & 281 \\
\hline 2012 & 271 \\
\hline 2013 & 283 \\
\hline 2014 & 343 \\
\hline 2015 & 489 \\
\hline 2016 & 426 \\
\hline
\end{tabular}

Tabela 7. Wskaźnik liczby zgłoszeń zdarzeń samolotów GA na licencję PPL

\begin{tabular}{|c|c|}
\hline Rok & Zgłoszenia na licencje PPL \\
\hline \hline 2007 & 0,1122 \\
\hline 2008 & 0,0869 \\
\hline 2009 & 0,0999 \\
\hline 2010 & 0,1131 \\
\hline 2011 & 0,1362 \\
\hline 2012 & 0,1061 \\
\hline 2013 & 0,0959 \\
\hline 2014 & 0,1069 \\
\hline 2015 & 0,1396 \\
\hline
\end{tabular}

Tabela 8. Wskaźnik zgłoszeń CA na operację

\begin{tabular}{|c|c|}
\hline Rok & Zgłoszenia na operacje \\
\hline \hline 2003 & 0,000197 \\
\hline 2004 & 0,000462 \\
\hline 2005 & 0,000661 \\
\hline 2006 & 0,000790 \\
\hline 2007 & 0,001362 \\
\hline 2008 & 0,002774 \\
\hline 2009 & 0,003220 \\
\hline 2010 & 0,004470 \\
\hline 2011 & 0,004613 \\
\hline 2012 & 0,004716 \\
\hline 2013 & 0,005900 \\
\hline 2014 & 0,006541 \\
\hline 2015 & 0,006988 \\
\hline
\end{tabular}


W wypadku zdarzeń związanych z lotnictwem komercyjnym można stwierdzić, że główną przyczyną wzrostu jest wzrost zgłaszalności (tabela 8). Od 2003 do 2015 roku liczba operacji wzrosła o $59 \%$. W tym samym czasie liczba zgłoszeń dotyczących CA wzrosła ponad 56-krotnie. Powoduje to, że wskaźnik zgłoszeń na operację wzrósł z 0,000197, aż do 0,006988, tj. ponad 35-krotnie (rys. 6).

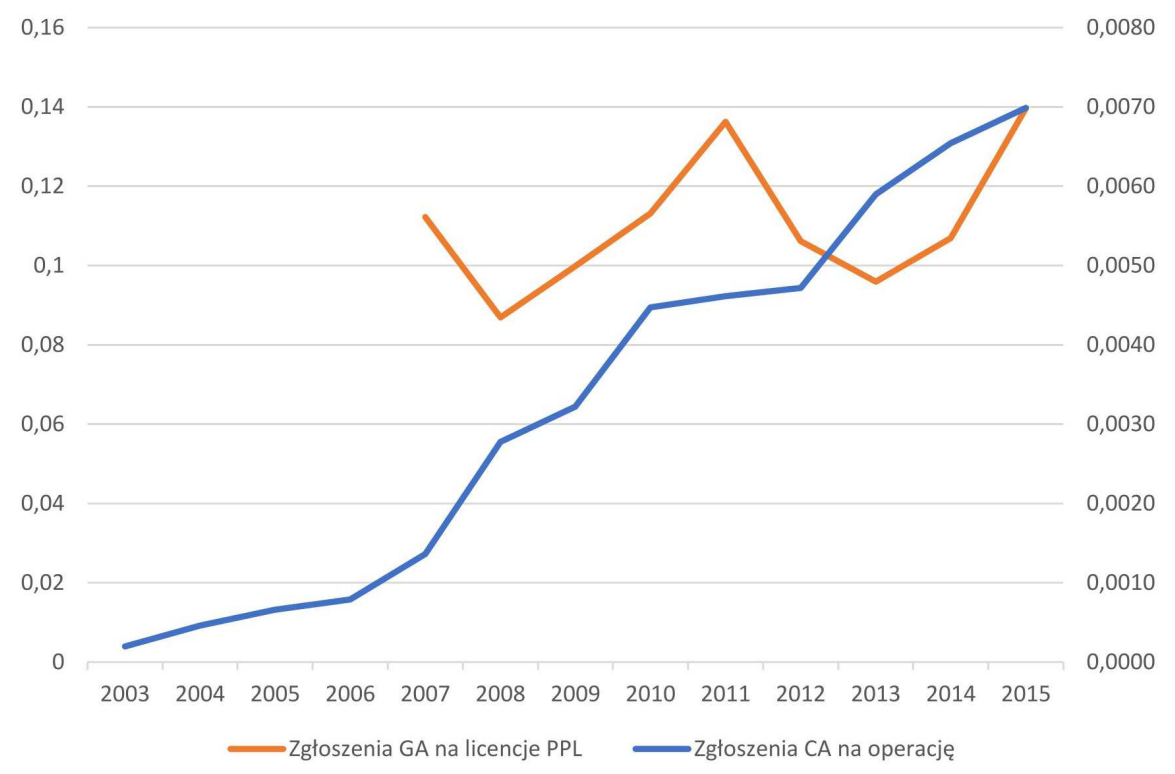

Rys. 6. Zmiana wskaźników zgłaszalności w czasie

\section{Statystyki zdarzeń - Generar Aviation}

Pomimo że zgłoszenia lotnictwa komercyjnego stanowią zdecydowaną większość napływających zgłoszeń, to jednak - jak wynika z poniższych statystyk - za większość zdarzeń z udziałem osób poszkodowanych odpowiada segment GA (rys. 7, tabela 9).

(a) 120

100

80

60

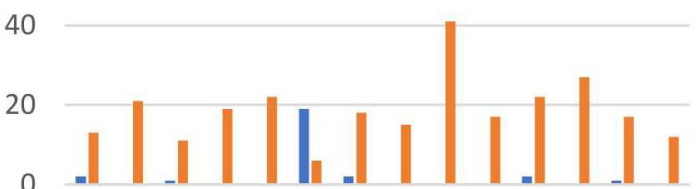

m

-CA Ofiary aGA Ofiary (b) 120

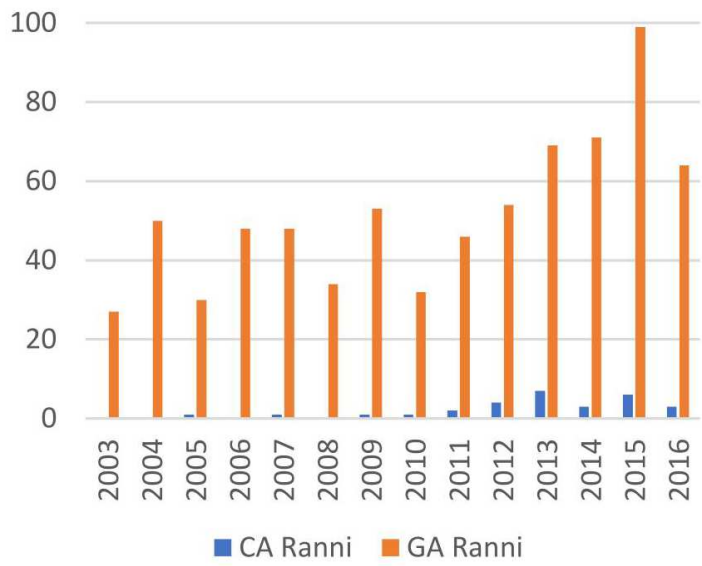

Rys. 7. Liczba: (a) ofiar śmiertelnych, (b) osób rannych (rok 2016 - dane do września)

W przypadku lotnictwa GA w większości zdarzeń, których skutkiem jest śmierć lub rany poszkodowanych, statkiem powietrznym jest samolot (rys. 8). Udział tego rodzaju maszyn to aż $83 \%$ wszystkich zdarzeń. Możemy również zauważyć stały wzrost liczby zdarzeń z osobami 
Tabela 9. Zestawienie osób poszkodowanych (rok 2016 - dane do września)

\begin{tabular}{|c|c|c|c|c|c|c|}
\hline \multirow{2}{*}{ Rok } & \multicolumn{2}{|c|}{ CA } & \multicolumn{2}{c|}{ GA } & \multicolumn{2}{c|}{ Razem } \\
\cline { 2 - 7 } & Ofiary & Ranni & Ofiary & Ranni & Ofiary & Ranni \\
\hline \hline 2003 & 2 & 0 & 13 & 27 & 15 & 27 \\
\hline 2004 & 0 & 0 & 21 & 50 & 21 & 50 \\
\hline 2005 & 1 & 1 & 11 & 30 & 12 & 31 \\
\hline 2006 & 0 & 0 & 19 & 48 & 19 & 48 \\
\hline 2007 & 0 & 1 & 22 & 48 & 22 & 49 \\
\hline 2008 & 19 & 0 & 6 & 34 & 25 & 34 \\
\hline 2009 & 2 & 1 & 18 & 53 & 20 & 54 \\
\hline 2010 & 0 & 1 & 15 & 32 & 15 & 33 \\
\hline 2011 & 0 & 2 & 41 & 46 & 41 & 48 \\
\hline 2012 & 0 & 4 & 17 & 54 & 17 & 58 \\
\hline 2013 & 2 & 7 & 22 & 69 & 24 & 76 \\
\hline 2014 & 0 & 3 & 27 & 71 & 27 & 74 \\
\hline 2015 & 1 & 6 & 17 & 99 & 18 & 105 \\
\hline 2016 & 0 & 3 & 12 & 64 & 12 & 67 \\
\hline
\end{tabular}

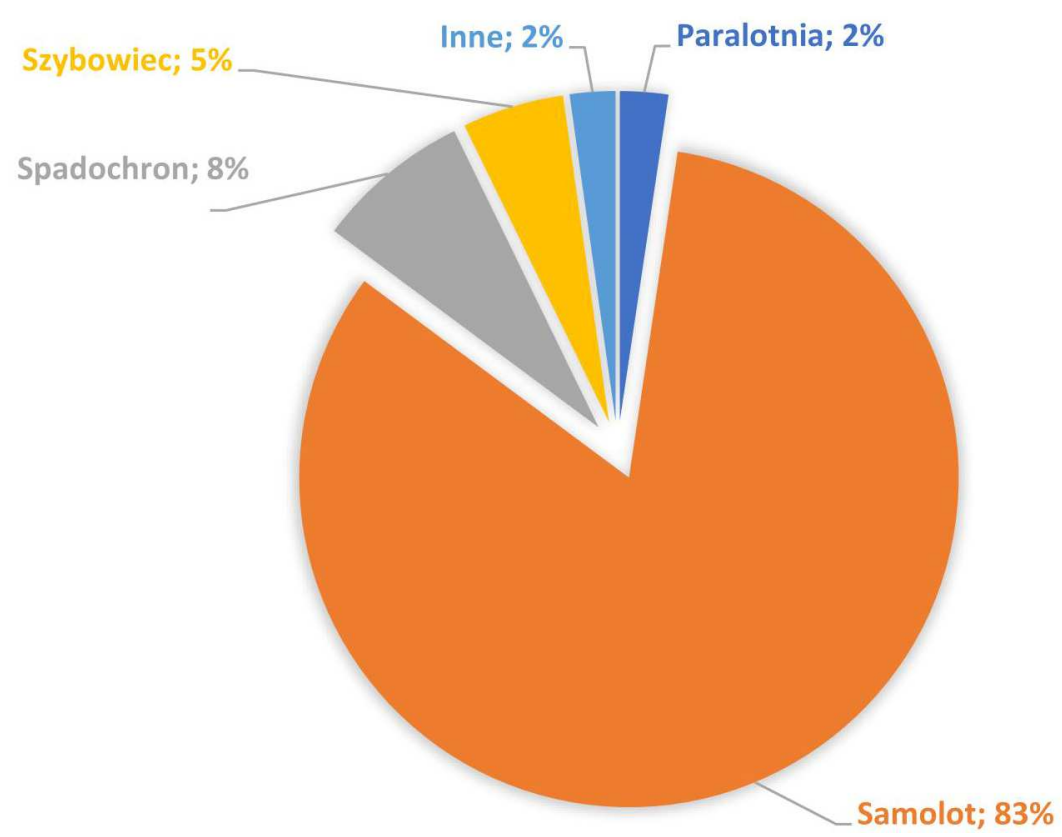

Rys. 8. Udział procentowy statków powietrznych - zdarzenia GA z poszkodowanymi

poszkodowanymi oraz osób rannych (rys. 9), jednak liczba ofiar śmiertelnych oscyluje wokół stałej wartości. Oznacza to, że pomimo większej liczby wydanych licencji oraz większej liczby zdarzeń z osobami poszkodowanymi, wypadki te są mniej tragiczne w skutkach. Wzrost liczby osób rannych wskazuje, że bardziej prawdopodobne podczas wypadku w czasie lotu GA staje się odniesienie obrażeń niż śmierć.

Można stwierdzić, że samoloty użytkowane podczas lotów GA staja się coraz bezpieczniejsze - podczas wypadków przeżywalność jest większa.

Po analizie 132 zdarzeń GA z poszkodowanymi, dla których wprowadzone zostały komentarze widać, że do większości wypadków dochodzi podczas lądowań, tak rutynowych, jak i awaryjnych (rys. 10a). Co jest warte uwagi, drugim najczęściej występującym komentarzem jest utrata noszenia, która wynika z przekroczenia krytycznego kąta natarcia. Analizując komentarze, można 


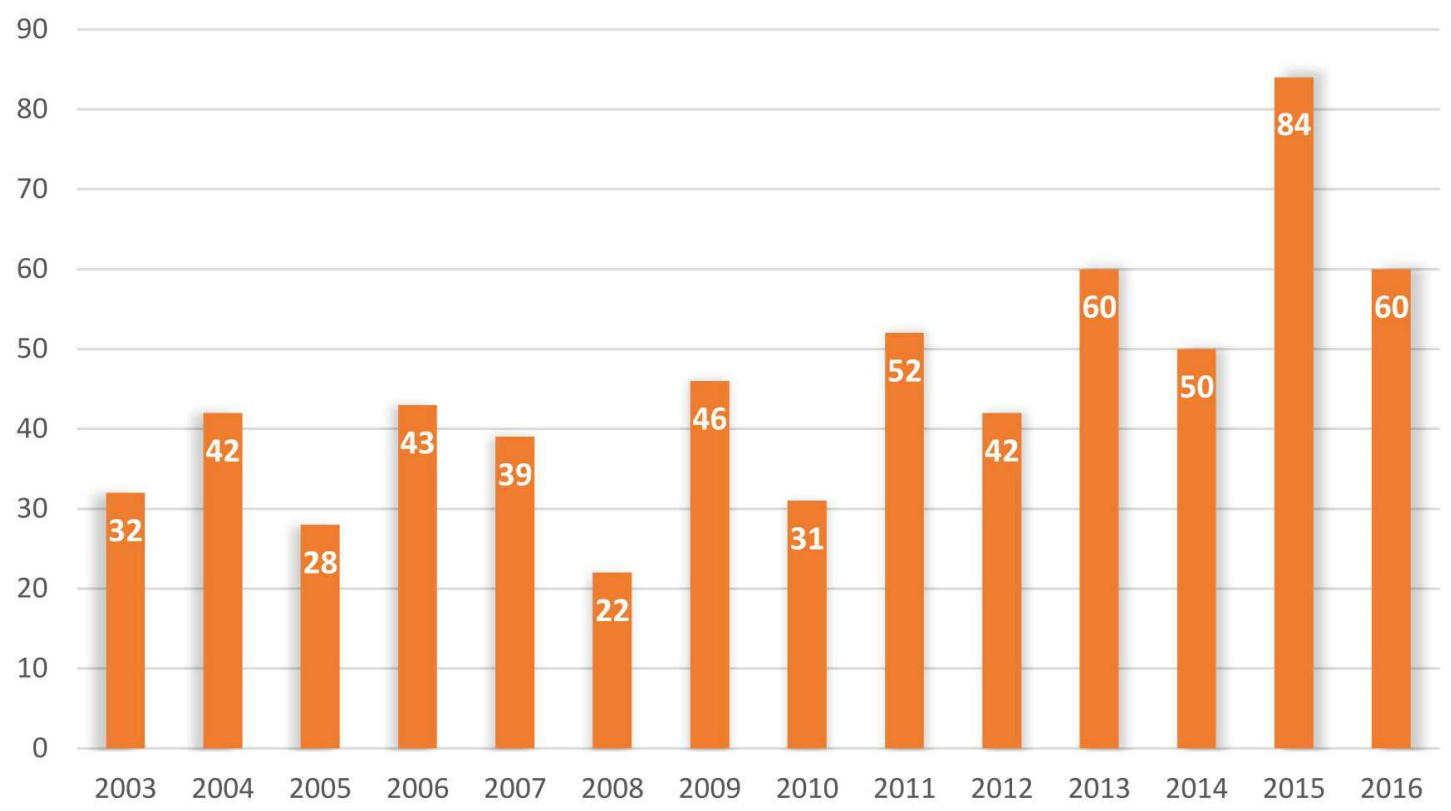

Rys. 9. Liczba zdarzeń samolotów GA z poszkodowanymi (rok 2016 - dane do września)

(a)

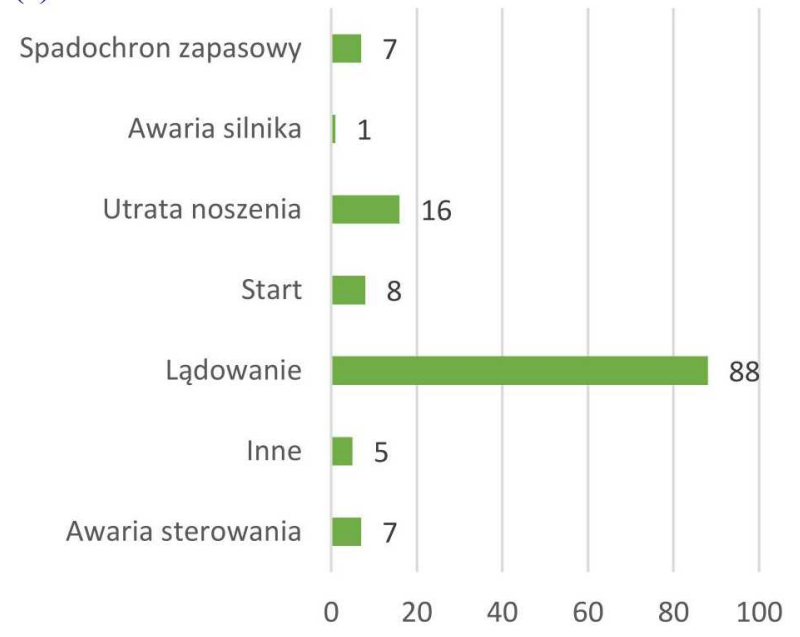

(b)

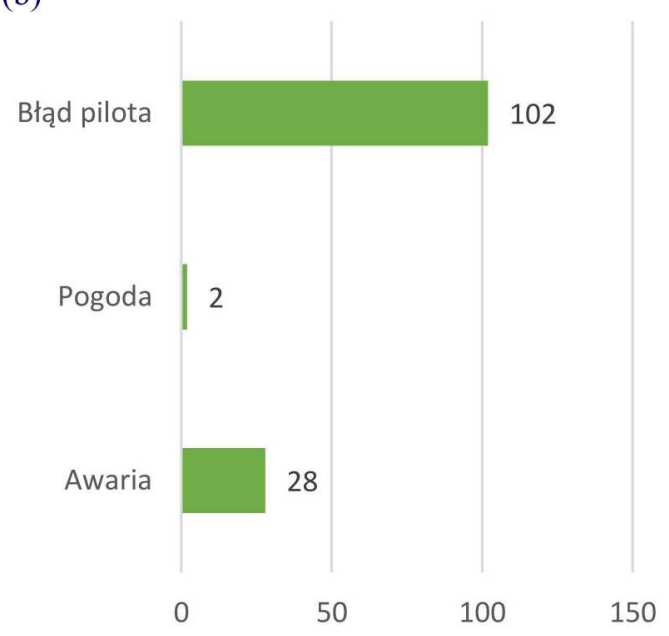

Rys. 10. Adnotacje z bazy

również podzielić zdarzenia na te spowodowane poprzez błąd pilota, awarie oraz warunki pogodowe. Z tych statystyk wyraźnie widać, że większość zdarzeń spowodowana jest przez błąd dowódcy statku powietrznego (rys. 10b).

Zgodnie z powyższymi danymi można stwierdzić, że dominującą przyczyną zdarzeń samolotów GA jest błąd pilota. Warty uwagi jest także ciągły wzrost udziału procentowego tej przyczyny, przez co awaryjność maszyn jest coraz mniej prawdopodobną przyczyną zdarzenia.

\section{Wypadki szybowcowe}

Ogólne statystyki wypadków szybowcowych w większości odpowiadają całości lotnictwa GA. Większość wypadków ma miejsce w drugim oraz trzecim kwartale podczas weekendów (rys. 11), a większość incydentów spowodowana jest przez błąd pilota (rys. 12). Warto natomiast zwrócić 
uwagę, na to, że liczba wypadków rocznie oscyluje wokół zbliżonych wartości, mimo ciągłego wzrostu liczby pilotów (rys. 13).

(a)

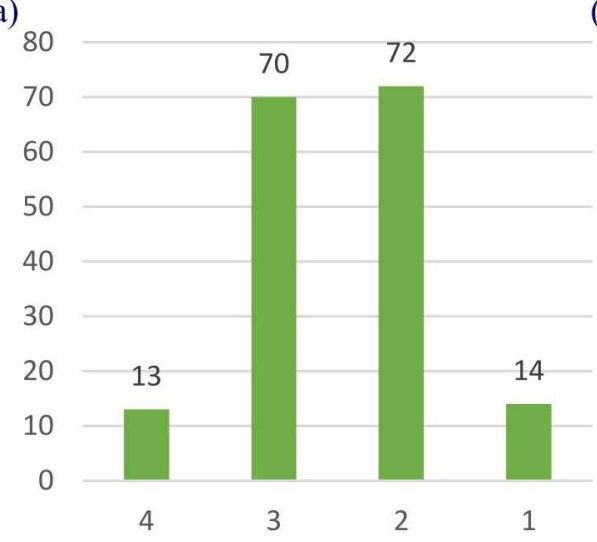

(b)

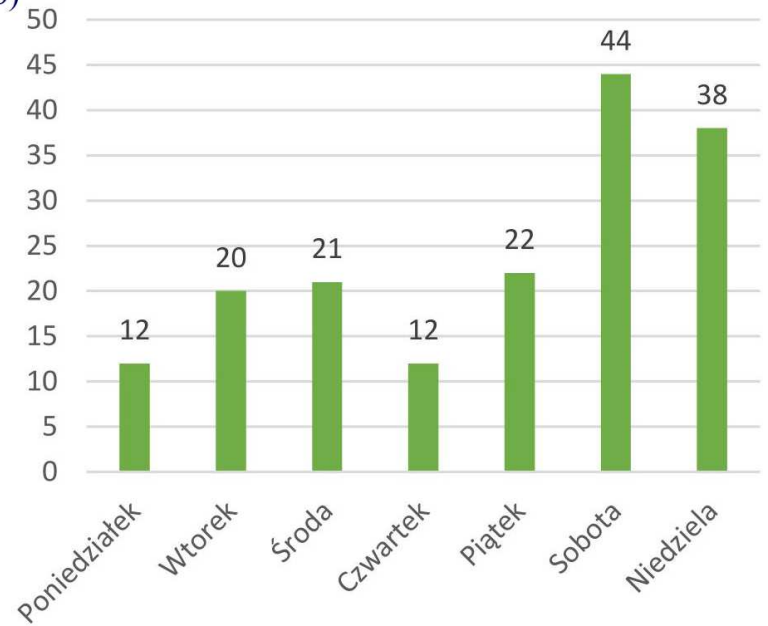

Rys. 11. Liczba wypadków szybowcowych: (a) w kwartale, (b) w dniach tygodnia

(a)

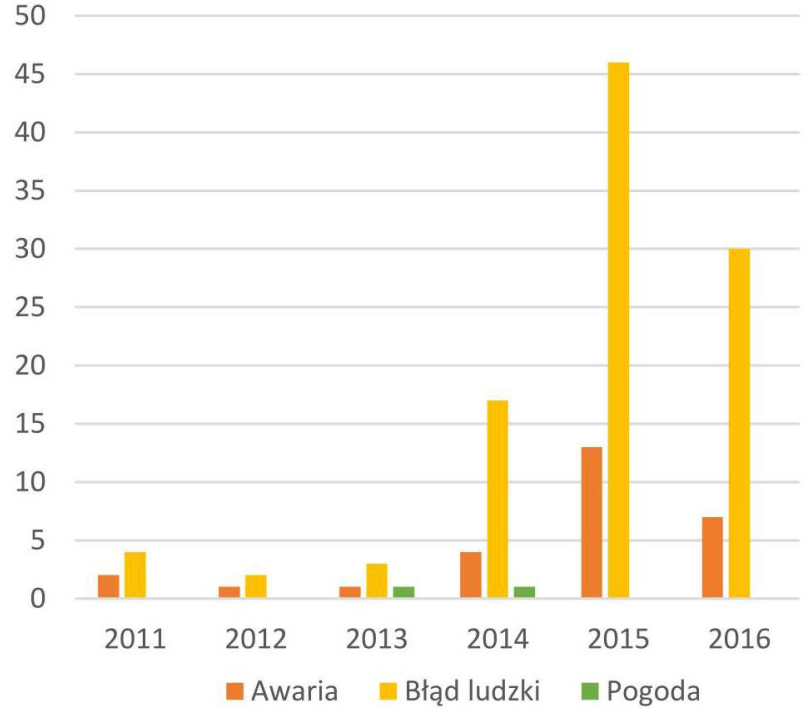

(b)

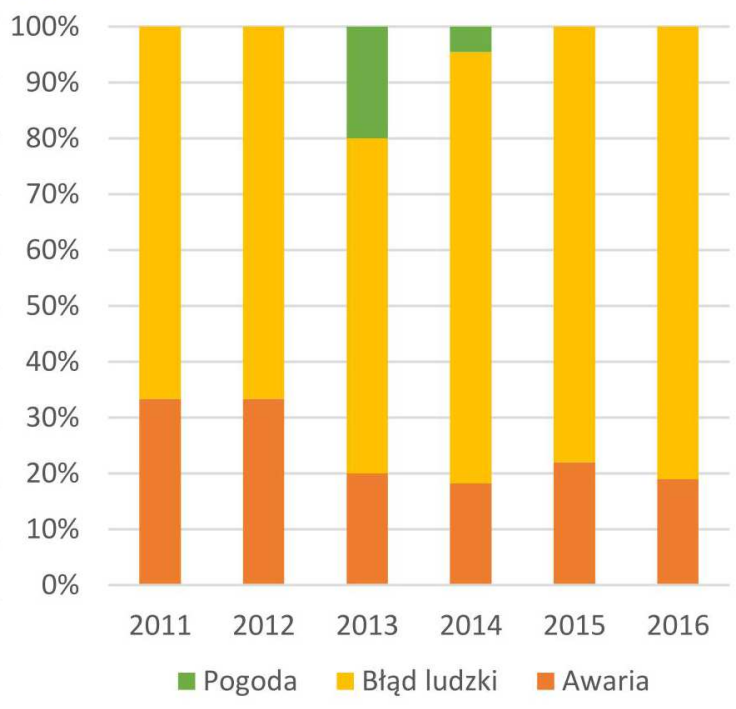

Rys. 12. (a) Adnotacje w czasie. (b) Adnotacje w czasie - udział wzgledny

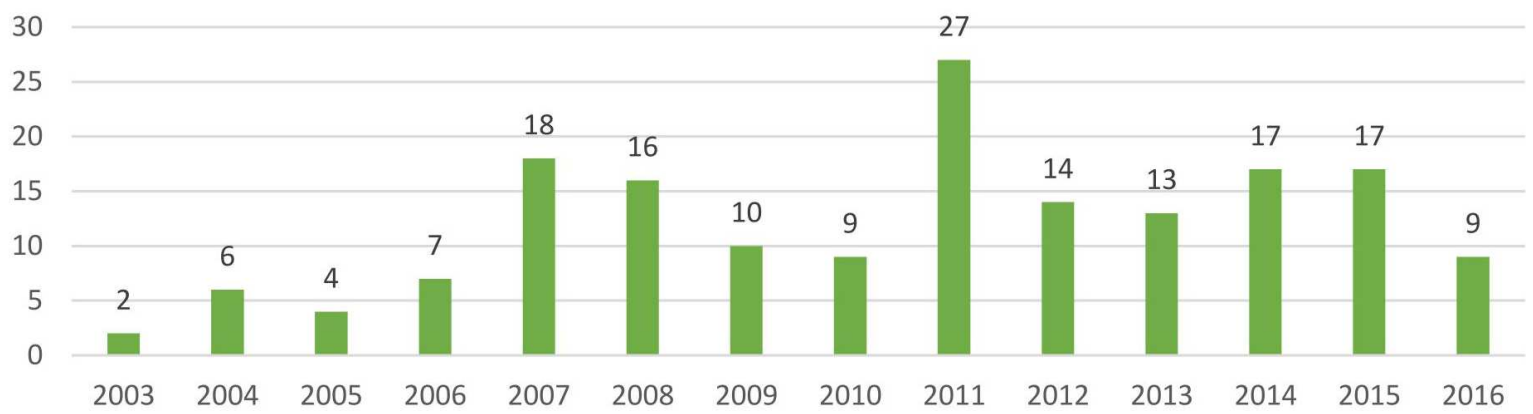

Rys. 13. Liczba wypadków szybowcowych w latach (rok 2016 - dane do września) 
Dokładnie przeanalizowano 32 zdarzenia lotnicze dotyczące szybowców, co do których raporty były dostępne. Z przedstawionych poniżej statystyk wynika, że większość wypadków szybowcowych zachodzi podczas lotów szkoleniowych lub laszujących (treningowych). Często piloci są pierwszy raz stawiani wobec nowej sytuacji, wykonując pierwszy lot nową maszyną, albo pierwsze lądowanie w terenie przygodnym, popełniając przy tym błędy prowadzące do wypadku.

Etapem lotu związanym $\mathrm{z}$ podwyższonym ryzykiem jest lądowanie $\mathrm{w}$ terenie przygodnym. Prawie połowa $\mathrm{z}$ analizowanych raportów opisywała zdarzenia zaistniałe właśnie $\mathrm{w}$ tej fazie lotu. Lądowanie w terenie nieprzystosowanym do operacji niesie ze sobą wiele zagrożeń związanych z ukształtowaniem terenu, roślinnością oraz ewentualnymi przeszkodami. Kluczowe dla bezpiecznego przeprowadzenia tego manewru jest wybór bezpiecznego miejsca z odpowiednim wyprzedzeniem, a potem przeprowadzenie manewru. Ponieważ nie jest to standardowa sytuacja, można zauważyć, że szczególnie piloci szkolący się popełniają błędy w tej fazie lotu. Warto również zwrócić uwagę,o że nie na wszystkie zdarzenia piloci mieli wpływ. Zdarzają się sytuacje, kiedy podczas lądowania $\mathrm{w}$ terenie przygodnym ukształtowanie terenu kryje niebezpieczeństwa niemożliwe do zauważenia z powietrza.

W wypadku lotnictwa szybowcowego zauważyć należy, że za znaczny odsetek analizowanych zdarzeń odpowiadają piloci. Aż 27 z $32(85 \%)$ zdarzeń było spowodowane błędem pilota. 22 z 27 (81\%) wypadków wydarzyło się podczas lotów szkoleniowych lub laszujących, większość z tych zdarzeń (17) miała miejsce podczas lądowania (rys. 14). Z analizowanych materiałów wynika, że tylko po 1 wypadku przypisano go wadzie materiałowej oraz wadliwie wykonanej naprawie.

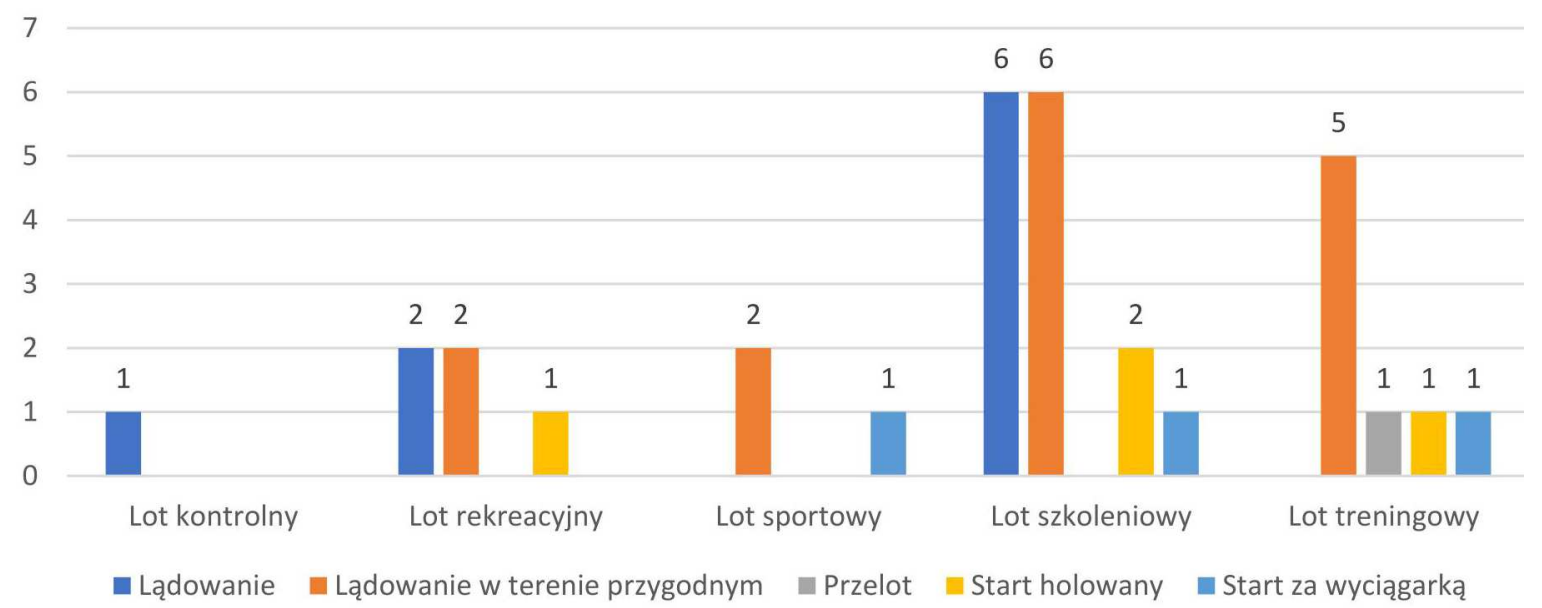

Rys. 14. Etap lotu zdarzenia z podziałem na kategorie lotu

Z poniższych danych można także wywnioskować, że krytycznymi momentami lotu szybowcowego jest start oraz lądowanie. Tylko 1 z 32 wypadków został przypisany do fazy przelotu (rys. 15 i 16).

Większość analizowanych incydentów powodowała lekkie (tj. rozklejenia materiałów, drobne pęknięcia, wgniecenia) lub poważne uszkodzenia szybowców (oderwanie elementów od konstrukcji). Według analizowanych danych całkowite zniszczenie konstrukcji szybowca lub brak uszkodzeń są mało prawdopodobne (rys. 17).

Na rys. 18 pokazano liczbę poszkodowanych w wypadkach szybowcowych. Ze względu na małą liczbę raportów dotyczących zdarzeń, w których osoby z załogi odniosły obrażenia lub poniosły śmierć, nie udało się ocenić wpływu poszczególnych analizowanych czynników na szanse przeżycia. 


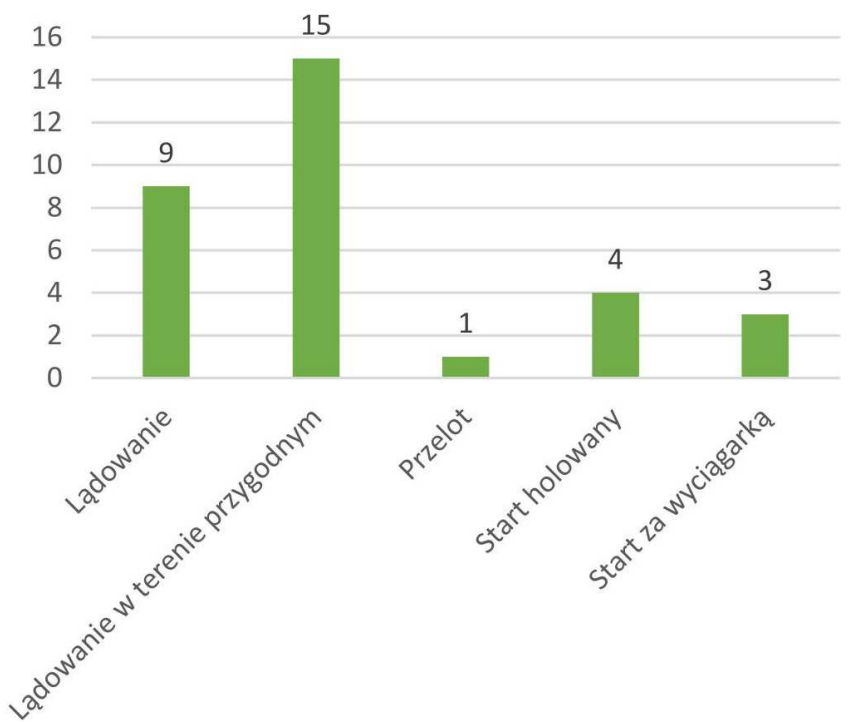

Rys. 15. Faza lotu

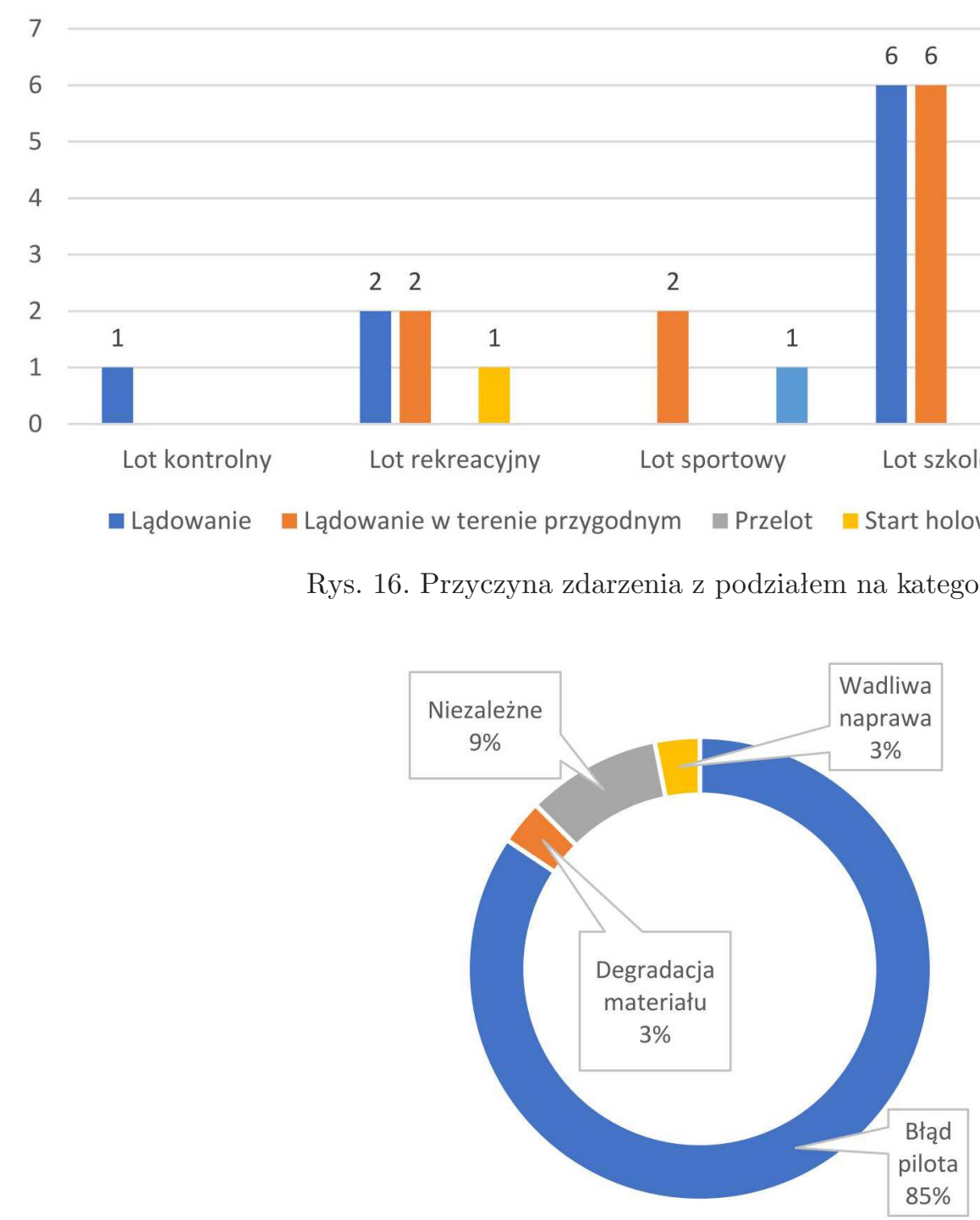

Rys. 17. Przyczyny zdarzeń 


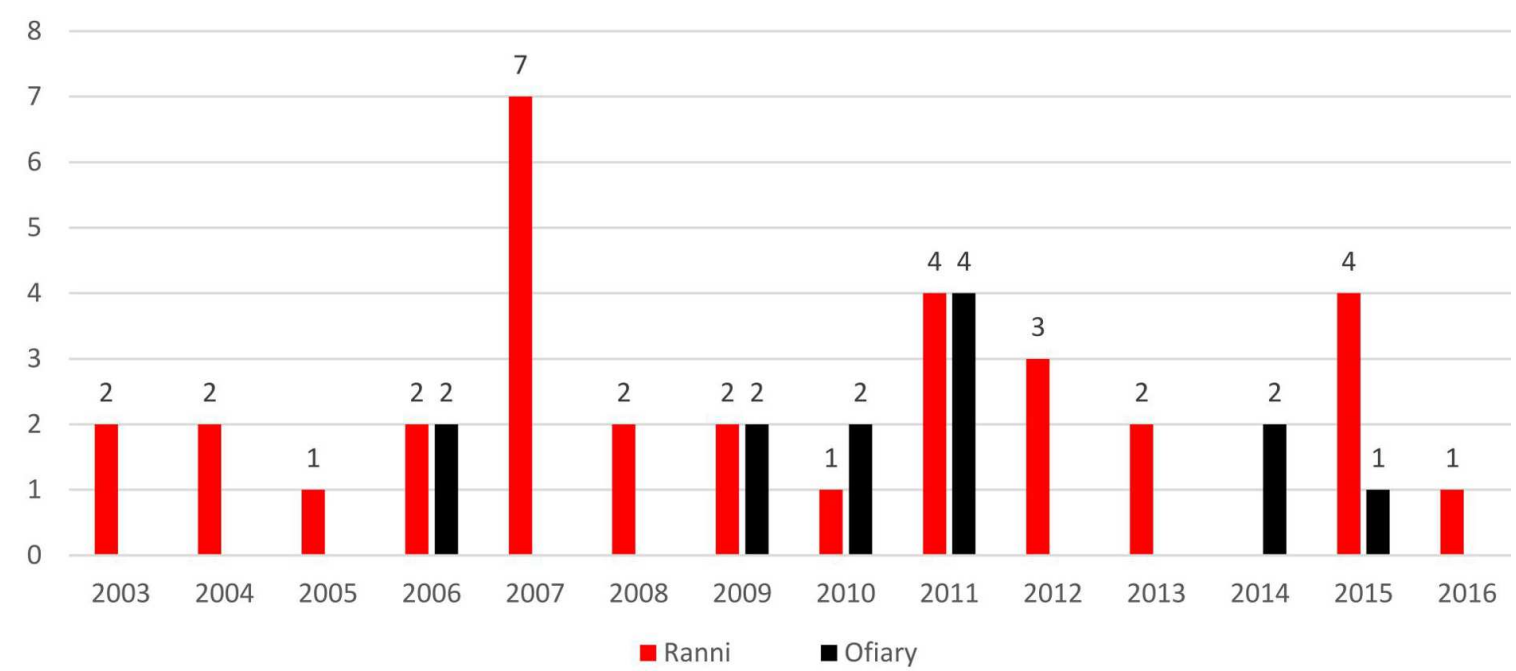

Rys. 18. Liczba poszkodowanych w wypadkach szybowcowych (rok 2016 - dane do września)

\section{Wnioski}

Dzięki powyższemu przedstawieniu danych zawartych $\mathrm{w}$ bazach oraz raportach PKBWL można sfomułować spostrzeżenia niemożliwe do zauważenia bez odpowiedniej analizy. Każda z trzech części powyższej analizy pozwala skupić się na innym segmencie lotnictwa.

Z zaprezentowanych statystyk wynika - po pierwsze - że wciąż istnieje potencjał na zwiększenie zgłaszalności zdarzeń dotyczących lotnictwa GA. Na przestrzeni analizowanych 12 lat wzrost liczby zgłoszeń jest zbliżony do wzrostu liczby wydanych licencji, co pozwala wnioskować, że użytkownicy statków powietrznych nie zgłaszają większej części zdarzeń, a ta liczba rośnie wraz z postępującą popularyzacją lotnictwa rekreacyjnego i coraz większą liczbą pilotów.

Po drugie - optymistycznym wnioskiem płynącym z analizy jest podwyższenie przeżywalności wypadków samolotów GA. W przedstawionym okresie wyraźny jest wzrost zdarzeń, w którym biorą udział osoby poszkodowane. Jednak mimo to liczba ofiar śmiertelnych tych wypadków oscyluje wokół stałej wartości. W tym samym czasie liczba osób rannych w analizowanych zdarzeniach rośnie około 3-krotnie, potwierdzając tym samym większą liczbę osób wykonujących loty. Taką zmianę można powiązać ze stosowaniem coraz bardziej zaawansowanych rozwiązań konstrukcyjnych w nowych maszynach, które zwiększają szanse przeżycia w razie wypadku.

Po trzecie - analiza wypadków szybowcowych dostarcza cennych informacji o tym, kiedy najczęściej dochodzi do wypadków. Statystyki wskazują na lądowania podczas lotów szkoleniowych jako na najbardziej prawdopodobne warunki zdarzenia lotniczego. Ważne jest również spostrzeżenie, że większość wypadków zachodzi podczas lądowania w terenie przygodnym. Powstaje pytanie, czy nie należałoby więcej uwagi skupić na tym manewrze podczas szkolenia, aby pierwsze samodzielne lądowanie poza lotniskiem nie było dla pilota pierwszym praktycznym podejściem do tego manewru.

Zaprezentowana powyżej metoda wykazuje dalszy potencjał badawczy. Dzięki poszerzeniu skali, poszerzenia tematyki oraz zwiększenia szczegółowości badań można tworzyć bardziej zaawansowane wskaźniki oraz próbować szukać powiązań między różnymi czynnikami, co nie było możliwe do wykonania na analizowanej tu próbie. Zidentyfikowanie obszarów, które statystycznie okażą się najbardziej niebezpieczne może pomóc zrozumieć kształtujące się trendy oraz spróbować wyeliminować przyczyny najczęstszych przyczyn zdarzeń. Zastosowanie tej metody wydaje się szczególnie produktywne dla segmentu GA, ponieważ tam dochodzi do największej liczby zdarzeń z największą liczbą poszkodowanych. Powiązanie różnych czynników może wskazać pewne wspólne przyczyny, które nie mogą być zidentyfikowane przy indywidualnym badaniu każdego zdarzenia. 


\section{Bibliografia}

1. Baza PKBWL od 2003 do 2015

2. https://www.ulc.gov.pl/pl/statystyki-analizy/statystyki-i-analizy-rynku-transportu-lotniczego

3. https://www.ulc.gov.pl/pl/personel-lotniczy/statystyki/1315-statystyki-personelu-lotniczego

\section{Analysis of trends of airplane situations by a database integration method}

Using a database integration method, incidents reported to National Commission for the Investigation of Aircraft Accidents between 2003 and 2015 were analysed. The mentioned method is characterised by its novelty, and however, it is not widely used, it is very effective and it allows one to combine and compare a wide range of data. The more detailed data were analysed, the more causes could be linked with circumstances of incidents. It was determined that it was possible to assess incident notification factor by making use of the original coefficient. What is more, it was confirmed that with an increased number of flights, the amount of notified incidents increased as well, what seems natural. However, at the same time, the number of fatalities remained about constant. Last but not least, incidents with gliders were meticulously analysed. It was possible to combine causes of accidents with the purpose and phase of flight. It was confirmed that the majority of incidents occurred during landing and it was related to human error. 